\title{
The economic benefits of whale watching in El Vizcaíno Biosphere Reserve, Mexico
}

\section{El beneficio económico del avistamiento de ballenas en la Reserva de la Biosfera El Vizcaíno, México}

\author{
LUdGer BRENNER ${ }^{*}$ \\ Marius MaYer ${ }^{* *}$ \\ Claudia Stadler ${ }^{* * *}$
}

\begin{abstract}
This paper attempts to determine the economic value generated by whale watching at El Vizcaino Biosphere Reserve/Lower California. Based on a representative sample survey, the analysis focuses on identifying specific visitor segments, their respective spending patterns, and the service sectors that profit. Results highlight that visitor spending generates a considerable gross turnover of just under \$3,000,000 USD, benefitting mostly local tourism businesses. In order to increase the economic benefits of whale watching as a means of fostering sustainable regional economic development, it is crucial to focus tourism planning and marketing tools on well-defined visitor segments to satisfy their specific needs and expectations.
\end{abstract}

Keywords: economic valuation, whale watching, biosphere reserves.

\section{Resumen}

En este artículo tratamos de determinar el valor económico generado mediante el avistamiento de ballenas en la Reserva de la Biosfera El Vizcaíno, Baja California. Con base en un sondeo representativo, identificamos los respectivos gastos de visitantes y los sectores económicos beneficiados. Los resultados muestran estos gastos realizados por los visitantes generan una venta bruta de casi tres millones de dólares estadounidenses, beneficiando principalmente negocios turísticos locales. Para incrementar los beneficios económicos del avistamiento de ballenas resulta primordial centrar la planificación turística y los instrumentos de mercadotécnica en segmentos de visitantes debidamente definidos, en el afán de satisfacer necesidades y expectativas.

Palabras clave: evaluación económica, avistamiento de ballenas, reservas de la biosfera.

\footnotetext{
*Universidad Autónoma Metropolitana unidad Iztapalapa, México, e-mail: bren@xanum.uam.mx.

** Ernst-Moritz-Arndt Universität Greifswald, Alemania, e-mail: marius.mayer@uni-greifswald.de

*** Ludwig-Maximilians-Universität München, Alemania, e-mail: claudi.star@gmx.de
} 


\section{Introduction}

Both the need to quantify the benefits that Protected Areas (PAs) provide to humans, and the morality of doing so, are controversial issues, as it is argued that unspoiled nature, health and human life are absolute, incommensurable values. Hence, any attempt to calculate the economic impacts generated directly or indirectly by PAs may be considered unnecessary or even unethical. Moreover, evaluation in general monetary terms tends to disregard crucial aspects such as social justice and the distribution of costs and benefits among stakeholders (Young, 1992). Besides, market failures demand governmental intervention to assure long-term environmental conservation, regardless of economic consequences (Pearce and Turner, 1990). But these arguments fall short of the mark, for any decision-making regarding conservation policies (e.g., establishing PAs or accepting changes in land use) necessarily implies an -often tacit- cost/benefit analysis. Thus, politicians and senior officials are constantly determining the value of nature through the political measures they take, or refuse to take, so monetary evaluations of the ecosystem services provided by PAs simply uncover implicit assessments and assigned priorities in regard to conflicting uses of resources (Mayer, 2013).

In this context, Pascual et al. (2010) point out several reasons to assess the values provided by PAs: first, the evaluation of direct use values such as nature-based tourism leads to comparisons of different -and often conflicting- land use options in monetary terms, thereby enhancing knowledge-based decision-making processes. But more importantly, the unvalued benefits of PAs and other kinds of public goods are likely to go unnoticed and so tend to be underestimated, especially when they conflict with potentially unsustainable forms of resource use (Aylward and Barbier, 1992). Second, quantifiable information on the benefits of PAs makes a good case for procuring political support for their continued existence, aside from ethical considerations (Pearce and Moran, 1994; Primack, 1995). If the economic impacts of ecosystem services become known, then PAs are much less likely to be considered "black holes" that absorb scarce financial resources, but generate no discernible economic benefits. Third, economic evaluations will help to advise local stakeholders, government officials and the general public on the monetary costs related to collapsing ecosystem services due to environmental degradation (Dixon and Sherman, 1990). Finally, quantifiable economic benefits generated by nature-based tourism generally enhance the acceptance of PAs among local populations, as they might outweigh the costs of opportunity that arise from restrictions imposed on resource use (Moisey, 2002; Brenner and De la Vega, 2014). 
Nevertheless, the quantification of the value generated by PAs entails several methodological challenges (see below) and so can provide only approximate numbers. Hence, the results of this study should not be regarded as a final or exclusive decision criterion applied to determine whether PAs are "useful" or not, but only as an additional factor that will aid in assessing the overall values - both tangible and intangible- that PAs provide.

According to Randall and Stoll (1983), the benefits of PAs can be categorized according to the concept of total economic value (considered as a comprehensive analytical framework for the economic valuation of nature's benefits to humans). Pascual et al. (2010) define this concept as the total value of all services generated by nature at present and in the future. Consequently, total economic value refers to all use and non-use components of ecosystem services measured in monetary units (Mayer and Job, 2014). In this context, use values are sub-divided into two categories: direct and indirect (figure 1). Non-use values consist of existence and bequest values which are generally difficult to quantify in economic terms. Also, option ${ }^{1}$ and quasi-option values are difficult to classify, as they might refer to either use values or non-use values (figure 1; see also Hanley and Barbier, 2009).

Direct use values result from: $a$ ) the economic impacts of public investment in PAs (i.e. park management or infrastructure works); $b$ ) the productive use of PAs (e.g., agriculture, timber extraction); $c$ ) the economic impact of nature-based tourism (i.e., lodging expenditures by visitors; see Moisey, 2002); d) the value of recreational experiences; ${ }^{2}$ and, $e$ ) intangible direct use values (e.g., use of PA labels for marketing, infrastructure effects, etc.). These direct use values are generally measurable in economic terms since they are tradable in formal markets. However, reliable data are often lacking (Chape et al., 2008).

In contrast, the indirect use values of PAs are associated with certain ecosystem services, ${ }^{3}$ such as biodiversity, naturally-occurring air and water purification, or $\mathrm{CO}_{2}$-sequestration, etc. (Pascual et al., 2010). These ecosystem services share the characteristic of being public goods, but are more difficult to evaluate since effective market forces generally fail

\footnotetext{
${ }^{1}$ Option values refer to potential -but currently unknown- benefits for future users, such as the possible medical use of certain plant species (Weisbrod, 1964).

${ }^{2}$ The value of the recreational experience is an intangible use value of PAs that accounts for the difference between total willingness to pay for PA visits and actual expenditures by PA visitors, though willingness to pay does not generate monetary flows, it only serves as an indicator of the recreational value provided by PAs.

${ }^{3}$ According to the Millennium Ecosystem Assessment, "ecosystem services" are differentiated into supporting services (e.g., soil formation, photosynthesis, nutrient cycling), provisioning services (food, water, timber etc.), regulating services (flood control, climate regulation etc.), and cultural services (recreational, aesthetic, and spiritual benefits) (MEA, 2005).
} 
to operate freely due to state interventions or free rider problems, among other factors (Farber et al., 2002). ${ }^{4}$

Due to the methodological challenges involved in valuing indirect use and non-use values, and the controversial debate surrounding non-use and option values, the monetary quantification of direct use values, especially those of nature-based tourism, has now become a key issue in the field of environmental studies and policies (Chape et al., 2008).

\section{Figure 1 \\ Total economic value of protected areas}

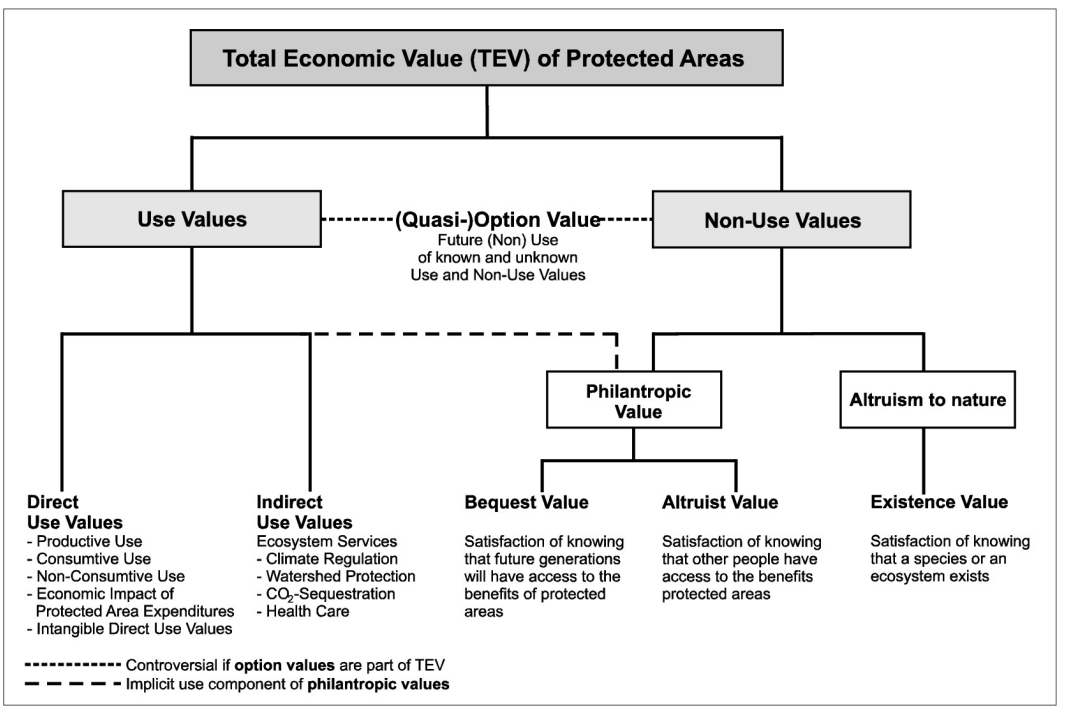

Sources: Mayer and Job, 2014, based on Barbier (1991), Munasinghe (1992), Job et al. (2009), Pascual et al. (2010) and Mayer (2013).

However, the aforementioned benefits come with considerable costs. As Dixon and Sherman (1990) point out, three categories of costs may hamper both the acceptance and effective management of PAs: $i$ ) direct costs (e.g., administration, payroll); ii), indirect costs (e.g., damage caused by wild animals); and, iii) costs of opportunity (e.g., income lost due to bans on fishing). The latter can be further sub-divided into losses related to limitations imposed on traditional resource use (e.g., timber extraction or hunting), on the one hand, and, on the other, restrictions on more

${ }^{4}$ Recently, efforts have been made to evaluate the economic value of certain ecosystem services (see, for example, Pascual et al., 2010) and establish institutional mechanisms for payments for the use of ecosystem services (Wunder, 2007). For example, several government aid programs have been formed to grant compensation payments to local communities to promote the conservation of forest cover and thus assure water supplies for several Mexican cities. 
capital-intensive uses of certain ecosystem services, such as generating hydrological power. It is also important to note that costs of opportunity are usually borne by local communities living inside PAs or in close proximity to them (Job and Mayer, 2012), a circumstance that can create trouble spots that affect public support for conservation policies (Brenner and De la Vega, 2014).

In many cases, tourism generates the lion's share of the direct use value generated by PAs (Mayer, 2014). For example, Newsome et al. (2002) estimate the share of ecotourism (including whale watching) in overall international tourism expenditures at about $20 \%$. This high proportion is due to the fact that many PAs are important tourist attractions, and that some, including El Vizcaíno Biosphere Reserve (EVBR), are considered unique because they offer visitors inimitable experiences. Consequently, the direct use value induced by nature-based tourism might foster economic development in PAs and surrounding areas (Woltering, 2012; Arnegger, 2014). This way, income from adequately-managed nature-based tourism could offset some of the costs of opportunity that PAs generate. There is also evidence that the tourism-related income that accrues to local stakeholders propitiates broader support for PAs while mitigating resistance to restrictions imposed on local communities (Brenner and De la Vega, 2014; Job et al., 2013). Given these facts, it is somewhat surprising that few systematic studies have been conducted to provide reliable data on the economic impact of tourist activities in Mexican PAs, with Arnegger's (2014) study on Sian Ka'an Biosphere Reserve being a notable exception. Therefore, we have ventured to make the first move by addressing the following questions: $a$ ) what is the direct economic value (measured in terms of gross turnover) of whale watching (WW) generated by visitor spending in EVBR, a World Natural Heritage Site that has become one of Mexico's prime nature-based tourism destinations; b) what is the spending behavior of specific visitor segments?; c) what types of local and non-local businesses benefit from this?; and, d) what effective means are there to increase the economic benefits generated by WW?

The paper begins with a brief description of the study area, focusing on the evolution of WW at EVBR. This is followed by an explanation of the methods applied to evaluate the direct economic value generated by WW, based on a representative survey conducted during the 2006-2007 season. Our results emphasize that visitor spending generates considerable gross turnover that benefits local tourism businesses, albeit spending behavior varied markedly among different visitor segments. The article concludes with some proposals for increasing the benefits of WW as a 
means of fostering sustainable and socially-balanced regional economic development in central Baja California.

\section{Whale watching in El Vizcaíno Biosphere Reserve}

WW is becoming increasingly important in global tourism (Gallagher and Hammerschlag, 2011; Cisneros-Montemayor et al., 2010; Orams, 2013, 2002; Hoyt, 2001), as its economic impact now constitutes an important motivating factor behind nature conservation and the imposition of bans on whaling (Bailey, 2012; Parsons and Draheim, 2009; Higham and Lusseau, 2008; Herrera and Hoagland, 2006). As a nonconsumptive and potentially sustainable activity, WW aims to reconcile the protection of marine mammals with the needs of local people in terms of offsetting costs of opportunity (Hoyt, 2005a). As the primary hibernation and mating area of Pacific grey whales (Eschrichtius robustus) EVBR is now a well-known tourism destination, whose shallow waters often allow close-range WW from late December to early April. Occasionally, visitors are even able to touch those cetaceans (Parsons et al., 2003; Ritter, 2004). Due to these conditions, it is no wonder that in 2006 about $85 \%$ of all whale watchers in Mexico were registered in the peninsula of Baja California, most of them in EVBR (Hoyt and Ińíguez, 2008).

EVBR is the largest Protected Area in Mexico $\left(25,468 \mathrm{~km}^{2} ; 3,624\right.$ $\mathrm{km}^{2}$ core zone and $21,844 \mathrm{~km}^{2}$ buffer zone). It is located in central Baja California State (figure 2) (INE, 2000). As early as 1972, Laguna de Ojo de Liebre (LOL) was established as the world's first Marine Protected Area in order to conserve the natural habitat of cetaceans (Hoyt, 2005b). From December to April, LOL and San Ignacio Lagoon (SIL, under legal protection since 1979) are mating sites for as many as 2,000 grey whales (Miller, 1975). In 1980, the nearby Guerrero Negro Lagoon was also declared a Protected Area, and eight years later these three whale sanctuaries were combined and enlarged to establish EVBR (Hoyt, 2005b). Since they constitute a crucial habitat for the entire grey whale population, the lagoons were declared a World Natural Heritage Site by Unesco in 1993 (Dedina and Young, 1995; INE, 2000). The area is sparsely populated (1.84 inhabitants per $\mathrm{km}^{2}$ ) (Inegi, 2014) due to the extreme aridity (50-70 $\mathrm{mm}$ per year) of the region, which virtually impedes agricultural use if irrigation is not available (INE, 2000). Nevertheless, large-scale common property units called ejidos (based on extensive cattle-raising) and privately-owned ranchos (producing capital-intensive, export-oriented and irrigation-dependent crops) were established in the 1970s through grants of government-owned lands and agricultural subsidies. The latter tend to deplete the scarce groundwater resources (Brenner and De la Vega, 
2014). In addition, large fish stocks triggered the establishment of several fishing camps at the reserve's western seaboard since the 1950s, which evolved into rural communities such as Bahía de Tortugas, Bahía Asunción and Punta Abreojos (see figure 2). As a result, the current economic structure of the EVBR area is characterized by large-scale salt production at the state-owned salt works (Guerrero Negro), irrigated export-oriented agriculture near the town of Vizcaíno, and seasonal WW at LOL and SIL (figure 2). Small-scale fishing (especially crayfish and lobster) and livestock rearing are other complementary economic activities (see Brenner and De la Vega, 2014; Brenner and Job, 2012; Young, 1999a and b; OrtegaRubio et al., 1998 for further details). As a consequence, different stakeholder groups claim the natural resources of EVBR, tour operators among them. However, this paper focuses on the tourism-driven direct economic value generated by the users of the reserve's maritime diversity.

\section{Figure 2}

\section{Location and zoning of El Vizcaíno Biosphere Reserve}

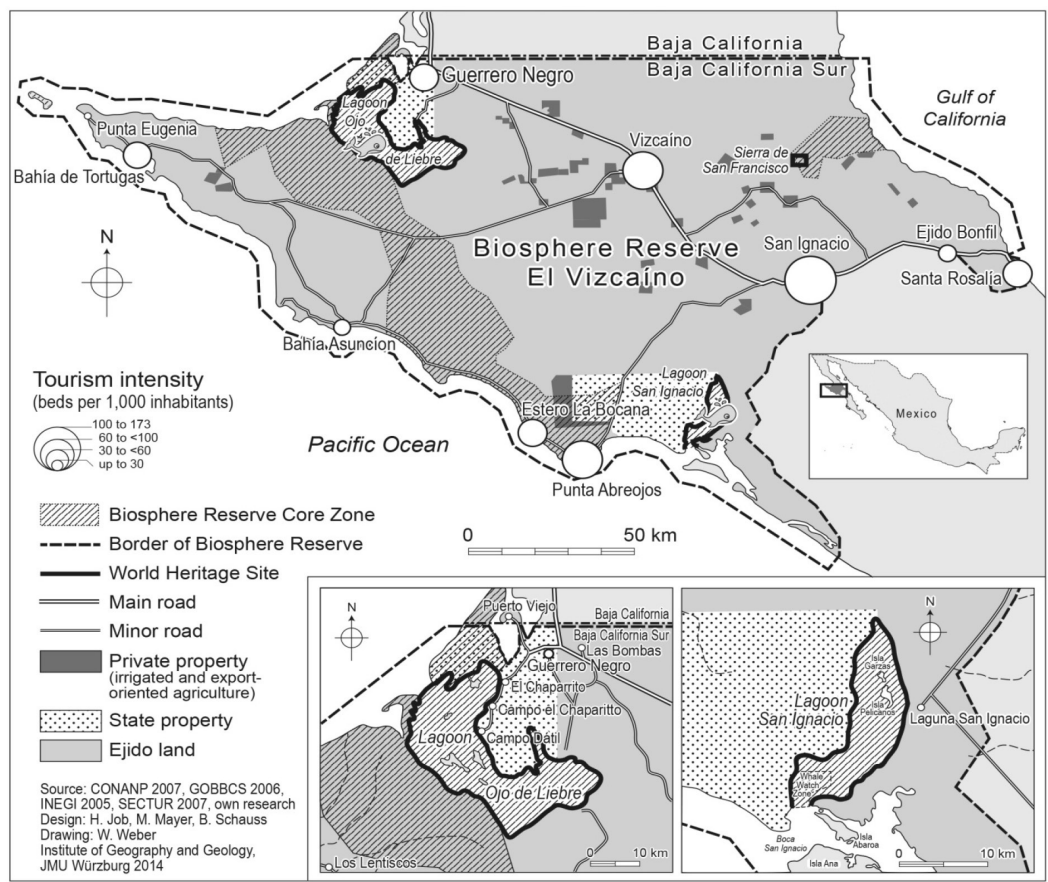

Source: designed by the authors. 
With respect to management efficiency, one striking fact is that the number of grey whales that hibernate and mate in EVBR has increased over the last 15 years, though naturally-occurring fluctuations are evident (figure 3). This could be related to measures taken by the National Commission on Protected Areas (Conanp) since the late 1990s (Brenner and De la Vega, 2014). The stability of the grey whale population can also be considered evidence of the long-term environmental sustainability of WW (Heckel et al., 2001).

WW-related tourist activities in EVBR began to develop in the early 1970s when several operators from San Diego (California, USA) began to offer boat tours to LOL and SIL. Back then, WW was controlled mainly by US-based tour operators, as virtually no tourist infrastructure was available locally (Dedina and Young, 1995; Hoyt, 2005b). Since the mid1990s, a growing number of visitors have reached EVBR overland by RV or car, on their way from the U.S. border to destinations in southern Baja California (or vice versa), an itinerary popular with retired North American tourists in wintertime. While passing through the Reserve on the only paved highway in central Baja California, most tourists use their necessary stopover to hire a WW tour as an "add-on" activity on their way south or north (Stadler, 2007). Consequently, as figure 4 shows, increasing numbers of visitors at LOL and SIL were registered between 1995 and 2014. During the 2004-2013 period, numbers averaged around 18,000 visits per season ${ }^{5}$. In the 2006-2007 season, when our visitor survey was conducted, Conanp counted 17,903 arrivals, of which 10,595 went to LOL, and 7,308 to SIL (figure 4).

The increase in tourist arrivals spurred the establishment of several locally-owned lodging facilities and tour operators at Guerrero Negro and San Ignacio. However, income generated by WW remained marginal until the mid-1990s, as "benefits (...) remain[ed] insignificant in economic terms (...)” (Breceda et al., 1995: 24). Likewise, Dedina and Young (1995) and Young (1999b) concluded that, despite the increasing numbers of visitors, WW continued to provide only additional seasonal income, of which only a "very small proportion (...) remains in the communities involved" (Young, 1999b: 606). Indeed, this author estimated that at the time only $1,2 \%$ of total expenditures by whale watchers on package tours at the SIL was spent locally (Young, 1999b).

At first, there was little control over WW activities, but the EVBR administration gradually managed to regulate boat traffic on the lagoons and the use of fishing gear and nets at LOL and SIL. Finally, in 1991,

${ }^{5}$ During the 2013-2014 season, Conanp reported an all-time maximum of 24,636 whale watchers, but offers no explanation for this extraordinary increase $(37,3 \%)$. 
Figure 3

Number of grey whales in the EVBR lagoons, 1996-2014

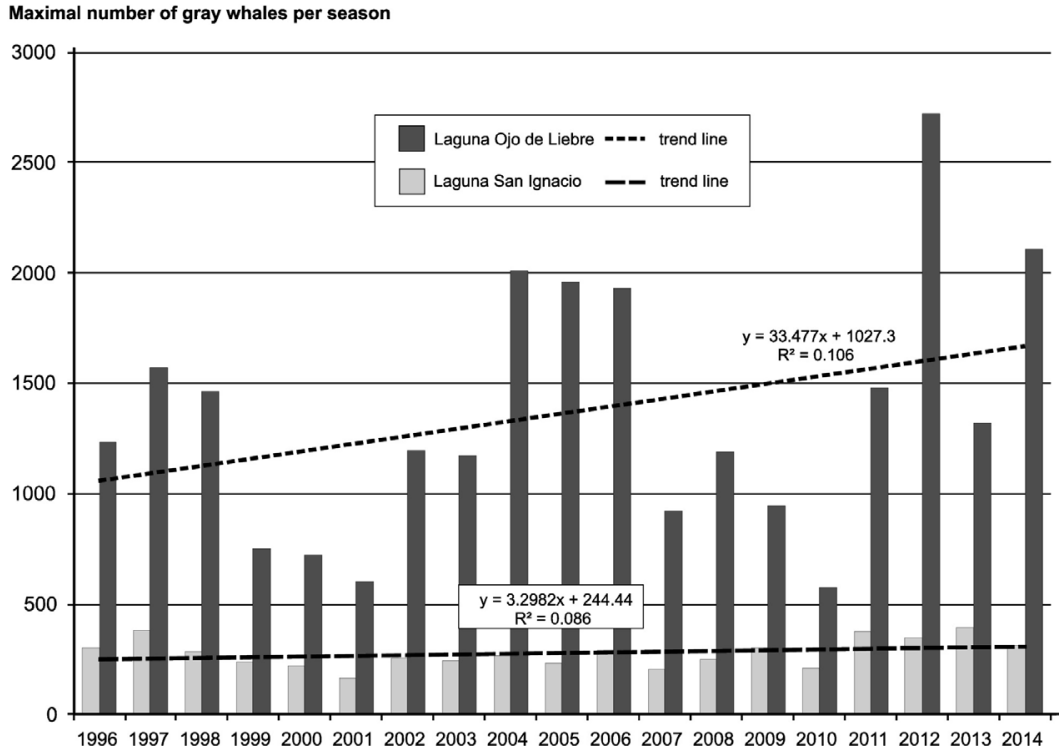

Source: elaborated by the authors based on data from Conanp, $2014 \mathrm{a}$.

Figure 4

Number of whale-watchers in the lagoons of EVBR, 1996-2014

\section{Number of whale watchers}

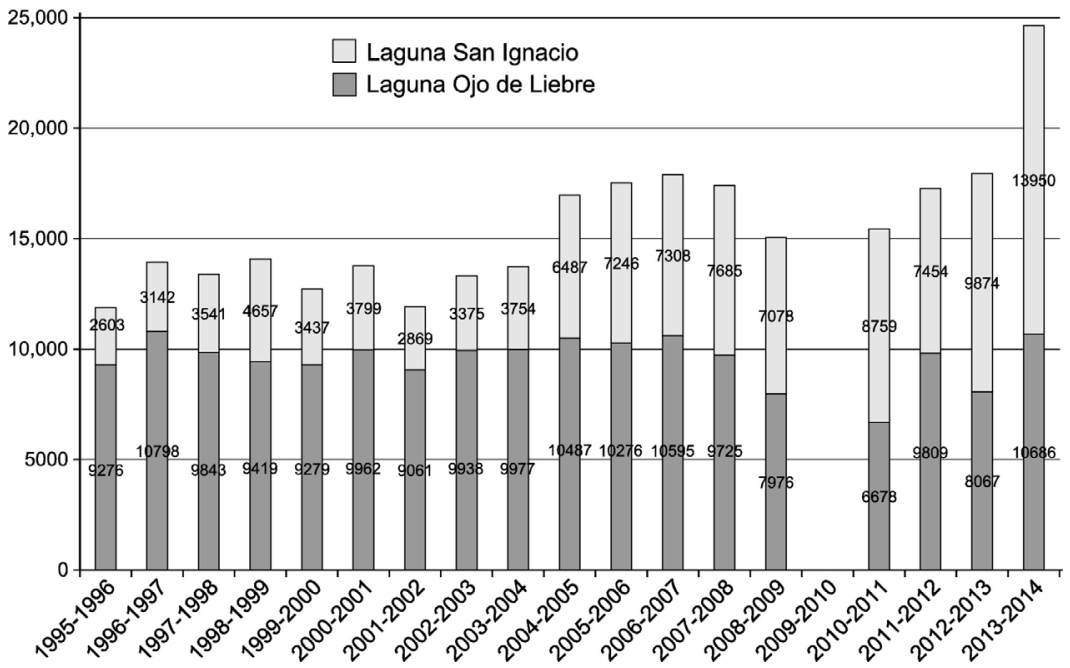

Note: visitor numbers for the 2009-2010 season are not available.

Source: elaborated by the authors based on data from Conanp $2014 \mathrm{~b}$. 
locals were granted exclusive rights to offer tourist services at both lagoons, as a "trade-off" for the ban imposed on fishing in the lagoons during the tourist season. Since then, foreign tour operators have been legally obliged to hire local boats and guides (Dedina and Young, 1995); a measure that has enhanced community involvement in WW, as local fishing cooperatives and entrepreneurs opened up businesses to offer visitors tours, food and accommodation (Young, 1999b; Hoyt, 2005b). Agersted (2006) notes that between 1994 and 2002 visitor numbers increased by 50\%, tourism-related employment by $100 \%$, and revenue from local tourism enterprises by $70 \%$ (considering an inflation rate of 55\%). By 2004, five locally-owned companies were offering WW tours, camping and lodging facilities, food, and transportation. In 2007, EVBR encompassed 53 accommodation businesses with a total of 1,448 beds, concentrated in Guerrero Negro (16) and San Ignacio (9).

However, if we consider the ratio of the number of beds per 1000 inhabitants ("tourist intensity") as an indicator of the relative economic importance of tourism at the local level, tourist activities are significant to the local economy of San Ignacio (which serves as a "hub" for visitors to SIL), and -to a considerably lesser extent- in Vizcaíno, Punta Abreojos and Guerrero Negro (figure 2). During the 2006-2007 WW season, a total of seven tour operators (three private businesses, three local fishing cooperatives and one ejido) offered WW tours in LOL, while six privatelyowned tour operators offered their services at SIL. However, despite the increases in visitors and tourism facilities since the late 1990s, WW is still far from being the primary source of income for the local population (Agersted, 2006), simply because WW is a highly-seasonal activity: $75 \%$ of visitors register in February and March when the grey whale population in the lagoons peaks (figure 5). Thus, WW depends heavily on the opportunity to observe close-up a large number of grey whales.

Unfortunately, there are no precise, up-to-date figures on the current economic impact of WW at local or regional level, though Hoyt and Ińíguez (2008) note that 15 tour operators operating in EVBR generated expenditures of $\$ 750,000$ USD in 2006 . According to these authors, some additional $\$ 8,274,000$ USD were spent by visitors, bringing total expenditures to $\$ 9,024,000$ USD. Such study has several shortcomings, however: first, the amount of visitors' spending or "indirect expenditures" (no less than $\$ 475 \mathrm{USD} /$ visitor/day) that they assumed (2008: 8) is not supported by any survey data and is only a rather rough estimate; ${ }^{6}$ and,

\footnotetext{
${ }^{6}$ Hoyt and Ińíguez (2008: 8) define "indirect expenditures" as total tourist expenditures other than fees for WW tours and international airfare, but it is unclear whether "indirect expenditures" are limited to spending within EVBR or include all expenses during the entire trip. In the latter case, WW-related expenditures would be clearly overestimated.
} 
Figure 5

Seasonal variation of whale watching in El Vizcaíno Biosphere Reserve

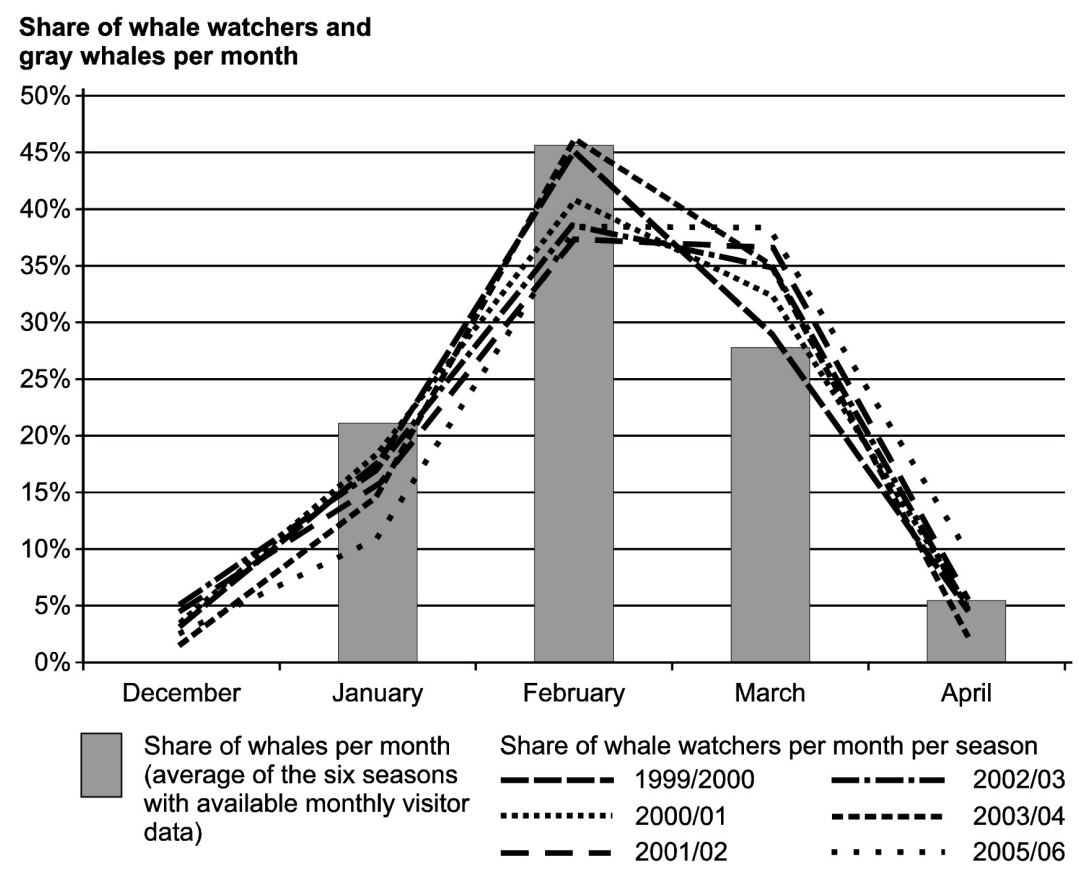

Note: no monthly WW data available for 2004-2005 or since 2005-2006.

Source: elaborated by the authors with data from Conanp $2014 \mathrm{a}$ and b.

second, they do not determine the distribution of revenue among the service-providers involved, which would shed light on the social dimension of the economic benefits generated by WW. Hence, the economic impact of WW in EVBR remains largely unknown. In addition, no studies have yet been conducted to calculate the leakages and multiplier effects generated by WW.

\section{Visitor types and gross turnover}

\subsection{Methodology}

The results of the present study are based on a visitor survey conducted in 2006-2007 (late December-early April), designed to calculate the gross turnover of whale watchers based on the expenditures of both overnight visitors and day-trippers who participated in guided tours at LOL and SIL. A random sample of 382 whale watchers was interviewed during, or 
after, WW tours in relatiFon to trip motivation, expenditures, and social and demographic characteristics, using standardized questionnaires. The interviews were conducted on 42 survey days during the entire whale watching season, scheduled ex ante according to statistical data provided by the EVBR administration. ${ }^{7}$ Survey sites were selected to ensure a representative sample in terms of visitor structure. ${ }^{8}$ Survey data were extrapolated to the total amount of visitors, based on weightings of the proportions of visitors registered at each lagoon. As entrance fees have been charged consistently during the WW seasons (\$3.82 USD/person in 2007), reliable total visitor numbers are available from 1995-1996 to 2012-2013.

Estimates of gross tourist spending $R^{g}$ by whale watchers were based on the methodology applied by Mayer et al. (2010). The number of visitor segments, their respective length of stay, and their mean daily expenditures per person were considered as follows:

$R^{g}=\left(V_{m o} \cdot \sum_{s=1}^{k} e_{m o s} \cdot L_{m o}\right)+\left(V_{m d} \cdot \sum_{s=1}^{k} e_{m d s}\right)+\left(V_{f o} \cdot \sum_{s=1}^{k} e_{f o s} \cdot L_{f o}\right)+\left(V_{f d} \cdot \sum_{s=1}^{k} e_{f d s}\right)$

$V=\quad$ Number of visitor days during the WW season

$m=$ Mexican visitors

$f=$ Foreign visitors

$o=$ Overnight visitors

$d=$ Day-trippers

$e=$ Mean daily expenditure per visitor type

$L=$ length of stay

$s=$ type of tourist service demanded by visitors $(1,2 \ldots, \mathrm{k})$.

\subsection{Visitor types}

Whale watchers are mainly working or retired adults, mostly US citizens $(56,8 \%) .{ }^{9}$ Due to the distance to the mainland and the high cost of trips,

\footnotetext{
${ }^{7}$ Based on Conanp visitor distribution statistics (figure 5). The survey was conducted over 3 days in December, 12 in January and February, respectively, 13 in March, and 2 in April (see also Stadler, 2007).

${ }^{8}$ A total of 219 interviews $(57,3 \%)$ were conducted at selected sites around LOL after consulting with Conanp officials. Another 163 respondents $(42,7 \%)$ were surveyed at SIL (see also Stadler, 2007). It is important to notice that the spatial distribution of our sample coincides with official statistics, as $59,2 \%$ of all whale watchers were registered in the 2006-2007 season at LOL, and 40,8\% at SIL (figure 4). Despite of the relatively small sample size, our survey turned out to be representative for the 2006/07 whale-watching season, as visitors had the same probability of being interviewed; which is the determining factor for representativeness (and not the total of conducted interviews; see also Mayer et al., 2010; Mayer, 2014).

${ }^{9}$ Over $60 \%$ of American visitors came from California (60,4\%).
} 
only one-fourth $(23,4 \%)$ of respondents were Mexican nationals, ${ }^{10}$ while the rest $(19,8 \%)$ were from other, mainly European, countries (16,6\%). Thus, incoming tourism is clearly prevalent at EVBR. In addition, 91,1\% of respondents travel in groups (couples, families or organized tours) that average 3,47 persons.

Table 1 summarizes the main characteristics of respondents. The vast majority $(86,7 \%)$ were overnight visitors (i.e., those who spend at least one night in EVBR), compared to 13,3\% day-trippers (i.e., those who spend the night outside EVBR). ${ }^{11}$ The average length of stay of all overnight visitors in EVBR is 3,42 days. Foreign overnight visitors represent the largest segment $(68,3 \%)$. As expected, the share of Mexicans among day-trippers is considerable (36,8\%), but less significant among overnight visitors (21,3\%). Nevertheless, Mexican overnight visitors tend to stay longer at EVBR (4,14 days) than foreigners (3,22 days). Four out of five respondents visited the Reserve on their own (i.e., no travel arrangements made prior to arrival), whereas $20,4 \%$ hired package tours from home, operated mainly by US-based companies.

With respect to the key motives for visiting EVBR, one-third (32,1\%) of respondents stated that the EVBR's status as a world-famous Biosphere Reserve and World Natural Heritage Site was particularly important (table 2); a finding that suggests that using the labels "Biosphere Reserve" and "World Heritage Site" could lead to more effective destination branding in the future. ${ }^{12}$ However, a large majority $(67,9 \%)$ stated that the Protected Area status mattered little, though overnight visitors highlyattracted by BR tend to stay longer than other visitors (4,34 vs. 2,99 days). ${ }^{13}$

Clearly, the most important motive was WW. In order to classify respondents according to their affinity to WW, we used three distinct features: a) the relevance of WW as a motive for visiting EVBR (very important/ important/less important/not important); b) the relevance of EVBR as a destination (primary destination/“one among others"/brief stopover on way to a primary destination); and, c) ratio: length of stay at EVBR/total

\footnotetext{
${ }^{10}$ Most Mexican visitors (84,1\%) came from the north and northwest (Baja California Peninsula).

${ }^{11}$ Most overland travelers prefer to spend at least one night in EVBR, as nearby tourist facilities are scarce, mostly in central Baja California.

${ }^{12}$ In order to determine the relevance of the status of Protected Area as a motive for visiting EVBR, we applied a set of successive questions, as suggested by Mayer et al. (2010): first, respondents were asked whether they knew there was a Protected Area in the region. Those who answered "Yes" were then asked about the specific category of Protected Area ("Biosphere Reserve" was the correct answer). Those who answered "Biosphere Reserve" were also asked about the relevance of being a BR for their decision to visit EVBR. Respondents stating "Very important" were considered "highlyattracted by BR", while all other visitors were labelled "Not particularly attracted by BR".

${ }^{13}$ The difference between the two segments is statistically significant (ANOVA F 4.393, p<0.038).
} 


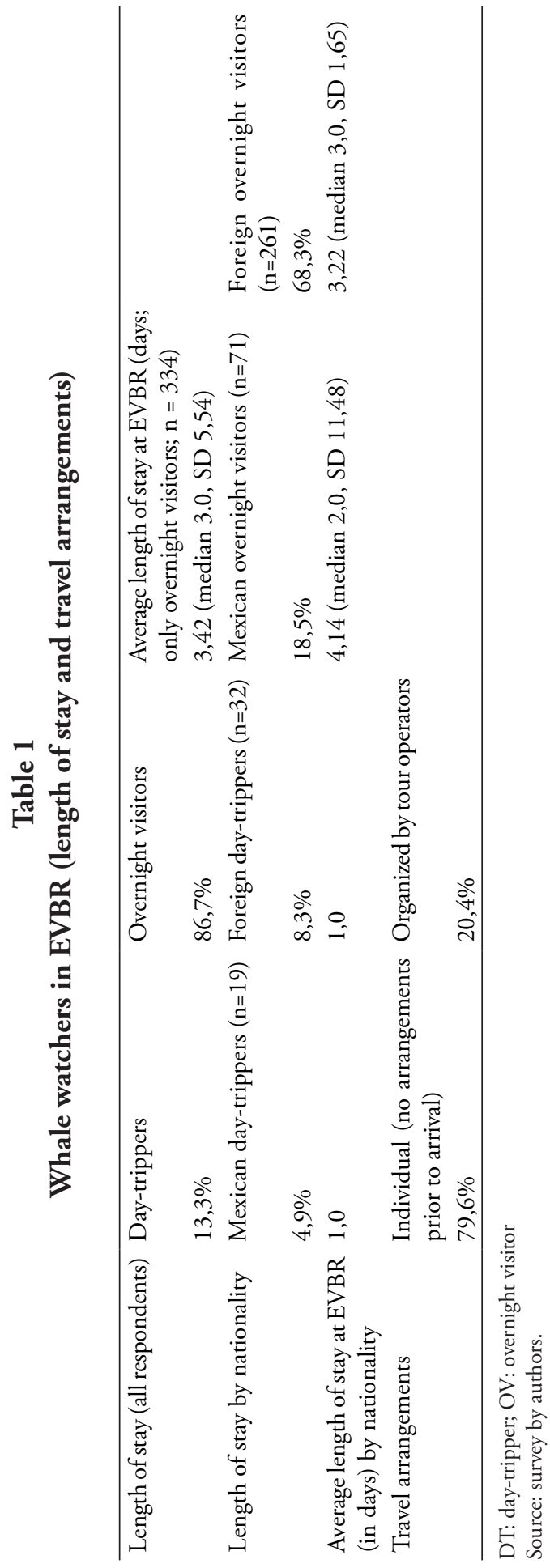




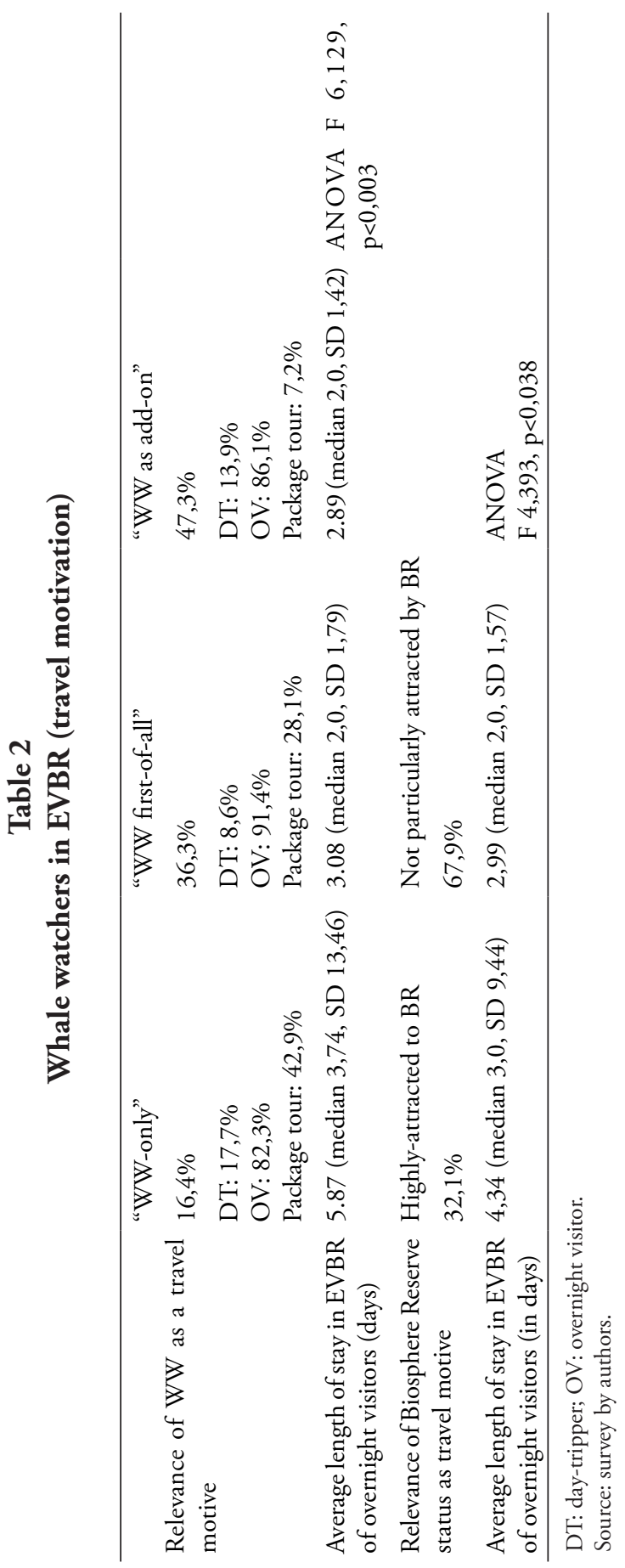


length of trip $(0-49 \%, 50-74 \%, 75-100 \%)$. This allowed us to identify three types of respondents with differing degrees of affinity to WW:

a) "WW-only" (16,4\%): WW is considered very important and the primary leisure activity; EVBR is the primary destination; visitors spend $75 \%$ or more of their available spare time at EVBR; almost a half travelled on package tours (42,9\%).

b) "WW first-of-all" (36,3\%): WW is considered quite important and the primary leisure activity; EVBR is one destination among others; $50-74 \%$ of available spare time is spent there; just over a quarter of this group hired package tours $(28,1 \%)$.

c) "WW as add-on" (47,3\%): All other whale watchers; only 7,2\% hired package tours.

As table 2 shows, almost half of the respondents (47,3\%) are "add-on whale watchers", but even so, over $52 \%$ classified as "whale-watchers first-of-all" $(36,3 \%)$ or "whale-watchers only" $(16,4 \%)$. These figures highlight the crucial role of WW as a trigger for tourism-related economic activities at EVBR and -in Leiper's (1990) terms- a nucleus for a tourist attraction. Moreover, the importance of WW as a reason for visiting the Reserve correlates positively with duration of stay, as the "WW-only" overnight visitors remained in EVBR for 5,87 days, while the respective figures for "first-of-all" and "add-on whale watchers" were 3,08 and 2,89 days. ${ }^{14}$

\subsection{Visitor spending and gross turnover}

Table 3 shows the expenditures of (independent) whale watchers.

On average, respondents spent $\$ 69,48 \mathrm{USD} /$ day at different locations in EVBR, ${ }^{15}$ of which $35 \%$ was for whale watching tours offered by local operators, $24,3 \%$ for food and beverages at local facilities, $17,7 \%$ for lodging (hotels, motels, camping facilities), and $10,5 \%$ for gasoline. In contrast to other studies (see Mayer et al., 2010; Arnegger, 2014), there were no statistically significant differences between the expenditures of day-trippers and overnight visitors.

Considering visitor numbers and types, daily expenditures per person, and length of stay in the survey area (see above), total revenue (or gross turnover) from whale watching tourism in EVBR was as follows (table 3 ): WW generated a total gross turnover of $\$ 2,938,000$ USD in the

\footnotetext{
${ }^{14}$ Differences are statistically significant (ANOVA F-value 6.13, $<<0.005$ ).

${ }^{15}$ Respondents were asked to estimate their spending in Mexican pesos, which were converted to USD at an exchange rate of $11,00 \mathrm{MXN}$ : $1.00 \mathrm{USD}$.
} 
2006-2007 season (not counting visitors on package tours). One-third (33\%) of this amount accrued to local tour operators, 24,9\% to restaurants at Guerrero Negro and San Ignacio, 19\% to businesses that provide accommodation (19\%), and 10,7\% to gas stations. Clearly, WW is highlydependent on North American and, to a lesser extent, European tourists, as more than two-thirds of the gross turnover is generated by foreign overnight visitors $(67,0 \%)$. In contrast, less than 30\% (29,3\%) is spent by Mexican overnight visitors. Finally, Mexican and foreign day-trippers do not generate significant turnover $(1,3 \%$ and $2,4 \%$, respectively).

Visitors' daily and overall expenditures differ according to their whale watching affinity, as on a daily basis the "WW-only" segment spends considerably less than the "WW first-of-all" and "WW as add-on" groups (table 4). However, these results must be taken with caution because "WW-only" overnight visitors stay almost twice as long as the other segments. Thus, this group had the highest overall expenditures during their stay at EVBR (\$267,20 USD), compared to $\$ 227,70$ and $\$ 211,80$ USD for the "first-of-all" and "add-on" whale-watchers, respectively. But due to their limited share among all EVBR visitors, the "WW-only" daytrippers and overnight visitors account for only $11,7 \%$ of overall gross turnover. In contrast, the "WW as add-on" segment generates 53,9\% and the "WW first-of-all" group 34,5\% of turnover. Consequently, "add-on" whale watchers should be considered the most important segment in economic terms.

Excluding package tourists, Mexican day-trippers are largely overrepresented among the "WW-only" guests $(24,3$ vs. $5,0 \%$ in the total sample), which might explain their relatively low daily expenditures. The share of Mexicans in the "WW-only" segment is also above average in the case of overnight visitors (48,6 vs. 19,1\%).

\section{Discussion and conclusions}

These results highlight several key issues. First, the direct use value (measured by total gross turnover) of just under $\$ 3,000,000$ USD generated by independent WW triggers regional economic development at EVBR, since revenue accrues primarily to local tourism businesses at Guerrero Negro and San Ignacio. Privately- and community-owned tour operators benefit most from WW, followed by small and medium-sized enterprises that offer food, accommodation, and gasoline. One particularly striking fact is that visitors spend most of their budget on WW tours while accepting relatively inexpensive food and accommodation services. As a result, guided WW tours on the two lagoons are the main drivers of tourismrelated revenue. In contrast, traditional services catering to visitors -such 
Table 3

Expenditures of whale watchers (arithmetic means by visitor type/ day) and gross turnover (in USD, not counting visitors on package tours) ${ }^{16}$

\begin{tabular}{lrrrrr}
\hline \multicolumn{1}{c}{$\begin{array}{l}\text { Visitor type } \\
\text { Nationality }\end{array}$} & \multicolumn{2}{c}{ Day-tripper } & \multicolumn{2}{c}{ Overnight visitors } & \\
& Mexican & Foreign & Mexican & Foreign & All visitors \\
\hline $\mathrm{N}$ & 18 & 21 & 66 & 200 & 304 \\
WW tour(1) & 30,16 & 39,40 & 22,11 & 22,92 & 24,30 \\
Other tours & 2,35 & 8,02 & 3,21 & 2,46 & 3,00 \\
Accommodation & 0,00 & 0,00 & 12,70 & 14,56 & 12,32 \\
Restaurants & 8,87 & 8,03 & 18,03 & 17,84 & 16,69 \\
Souvenirs & 0,00 & 1,51 & 1,32 & 1,03 & 1,07 \\
Shopping (other items) & 0,00 & 0,00 & 0,55 & 0,55 & 0,48 \\
Tips & 1,13 & 3,30 & 2,02 & 2,36 & 2,28 \\
Gasoline & 4,59 & 3,63 & 6,44 & 8,25 & 7,33 \\
Other & 0,00 & 9,11 & 1,79 & 1,81 & 2,20 \\
Total & 47,10 & 73,00 & 68,17 & 71,78 & 69,65 \\
Number of visitors & 826 & 984 & 3,079 & 9,363 & 14,252 \\
Length of stay (days) & 1,00 & 1,00 & 4,09 & 2,93 & \\
Visitor days & 826 & 984 & 12,593 & 27,434 & 41,837 \\
Gross turnover & 38,905 & 71,832 & 858,472 & $1,969,183$ & $2,938,392$ \\
& $1,3 \%$ & $2,4 \%$ & $29,2 \%$ & $67,0 \%$ & $100,0 \%$ \\
\hline
\end{tabular}

$\mathrm{n}=304$

(1) Day-trippers spend more on the WW tours on a daily basis ( $\$ 35,14$ USD) than overnight visitors (\$22,72 USD), because the latter stay for several days, though they take only one tour.

Source: authors' research.

${ }^{16}$ Expenditures by visitors on organized package tours (20,4\% of the sample) are discounted because respondents were unaware of the proportion of expenditures accruing to local service providers. Also, these respondents were unable to itemize costs. Thus, the sample size shown in table 3 is limited to 304 cases. For this reason, the estimated turnover of $\$ 2,938$ million USD should be considered conservative. 


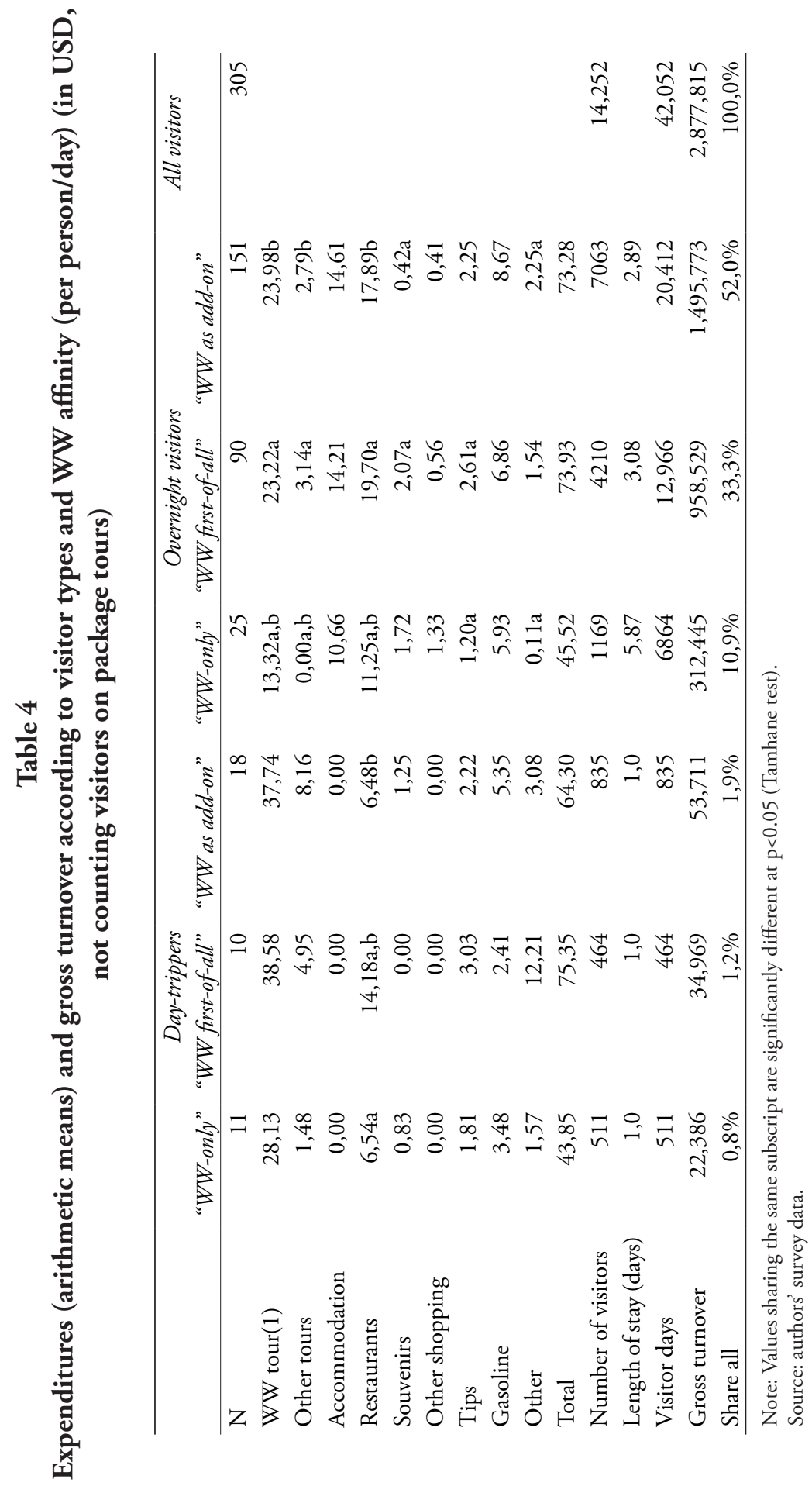


as hotels, motels and restaurants at Guerrero Negro and San Ignacio-are less relevant in terms of income generation, highlighting the significance that many respondents (especially the "WW-only" and "WW first-of-all" segments) attribute to WW as the motive for visiting EVBR. Hence, our results are contrary to Young's (1999b) study, which argues that only a small proportion of visitors' expenditures remain in local communities. This important finding can be explained by the increasing involvement of local entrepreneurs in WW businesses since the late 1990s. Our results also prove that Hoyt and Ińíguez (2008) overestimated the amount of visitors' indirect expenditures, which led them to overvalue the economic importance of WW.

Our study does have some limitations, as it does not consider the leakages that may result from inputs purchased outside the region (e.g. food, beverages, technical equipment), that would reduce impacts on the local and regional economy; nor does it contemplate the possible multiplier effects generated by tourist expenditures. Hence, further research is necessary to quantify the overall economic impact of WW at the local and regional levels. Also, additional surveys on multiplier effects and impacts on employment (beyond the topics studied herein) would shed light on the overall economic effects of nature-based tourism in Mexico.

Second, the gross turnover generated by WW at EVBR is considerable when compared to other Mexican nature-based tourism destinations. Applying the same methods as ours for the year 2006, Arnegger (2014: 157) calculated a total gross turnover of $\$ 4,500,000$ USD in Sian Ka'an BR (Quintana Roo, southeastern Mexico), though most of the money (about \$2,900,000 USD) was spent in adjacent tourist resorts outside the Reserve's boundaries and so did not benefit businesses inside it. Moreover, average daily expenditures at that reserve (\$18.28 USD) were almost four times less than in the case of EVBR $(\$ 69,48$ USD). Though making direct comparisons between these two PAs is problematic because of disparities in their respective levels of socioeconomic development and visitor numbers $\left(89,765\right.$ at Sian Ka'an vs. 17,903 whale watchers ${ }^{17}$ at EVBR), the marked differences in these figures highlight the current role of WW as a trigger for regional development in EVBR, however additional comparative studies are required to gain insight into the impacts of WW at national level.

Third, evidence suggests that revenues from WW generate both active and passive support for EVBR. As Brenner and De la Vega (2014) demonstrate, tourism promotion by governmental institutions and

\footnotetext{
${ }^{17}$ Not counting off-season visitors (May-Nov.) or tourists who do not hire WW tours during their stay.
} 
effective law enforcement to regulate WW at LOL and SIL have been perceived as both successful and economically-beneficial by most actors involved in nature-based tourism. The qualitative in-depth interviews conducted by these authors revealed that most respondents considered these measures suitable for enhancing the quality of services offered by local tour operators, and thus lead to increased revenues. Accordingly, most tourism cooperatives and private service providers now accept the regulations and actively support most measures taken by the management authority (ibid.). It is fair to say that broad support for the current governance regime depends at least partly on WW as an alternative source of income. Direct use value generated by WW has therefore fostered successful implementation of UNESCO paradigm of Biosphere Reserves in this area of Baja California.

Fourth, due to its notable impact on the economies of Guerrero Negro and San Ignacio, WW offsets, at least partially, the overall costs of opportunity related to the ban on fishing. Stadler (2007) estimates the income lost from the 4-month ban on rock lobster fishing in LOL during the whale hibernating season at approximately $\$ 400,000$ USD. At the same time, the WW tour operators in LOL alone realize a gross turnover of more than $\$ 600,000$ USD. Thus, the costs of opportunity related to banning lobster fishing are likely overcompensated by WW-induced income. However, more data on gross turnover in specific industries (i.e., fishing, agriculture, salt production, etc.) are required to assess in detail the scope and scale of the overall costs of opportunity that arise from restrictions on resource use, including possible trade-offs.

Fifth, revenue is generated mostly by North American overnight visitors with a specific interest in WW, so special attention should be paid to the "WW-only" and "WW first-of-all" segments, as they generate the bulk of expenditures. Also, these visitors are likely to spend more on additional WW-related leisure activities such as walking tours or scenic flights if they are available. Therefore, WW should be regarded as of special interest for incoming tourism which contributes not only to regional economic development, but also to increasing revenue from foreign exchange. While not comparable in terms of economic relevance with sun-and-sea tourism at Mexico's major resorts, nature-based tourism in Baja California is broadening the range of the country's export products and services. In this context, more data on specific visitor features would help to coordinate management activities at Mexico's WW sites. Spending by Mexican visitors is noteworthy -though much less significant- since they tend to stay longer than foreigners.

We suggest funding further research in order to shed light on the features of specific visitor types and develop suitable marketing actions 
targeted to the three segments we have identified. Moreover, measures should be taken to increase the number of Mexican visitors, which would enhance impacts on regional economic development. In addition, other sights at EVBR -such as the cave painting near San Ignacio or the world's largest salt production unit at Guerrero Negro- could be promoted more professionally to generate value from these unique tourist attractions. Finally, it would be helpful to quantify the direct use value of all economic activities present at EVBR, such as fishing, stock farming, irrigation agriculture and salt production. By applying suitable methods (an employment assessment might be the easiest way), this endeavor could provide specific information on the total use value provided by this reserve, as well as on existing or potential opportunity costs due to restrictions on resource use. In this spirit, a direct comparison of conflicting land use options in monetary terms would enhance a knowledge-based management of Mexico's protected areas.

\section{Acknowledgments}

The authors would like to thank Bernadette Schauss and Hubert Job (Julius-Maximilians-Universität Würzburg/Germany), as well as the current and former staff of El Vizcaíno Biosphere Reserve, notably Francisco Cota Ceseña, José Antonio López Espinoza and Héctor Toledo, for their kind support during fieldwork and their helpful comments.

\section{References}

Agersted, Peter (2006), "Evaluating ecotourism in Mexico's Biosphere Reserves-whale watching activities in the World Heritage Site of Laguna San Ignacio, Baja California Sur, Mexico, 1994-2002”, master's thesis, University of British Columbia-Department of Geography.

Arnegger, Julius (2014), "Protected areas. The tourist bubble and regional economic development. Two case studies from Mexico and Morocco", Würzburger Geographische Arbeiten 110, Institut für Geographie und Geologie der Julius-Maximilians-Universität Würzburg y Geographische Gesellschaft Würzburg, Würzburg, $<$ http://opus.bibliothek.uni-wuerzburg.de/frontdoor/index/ index/docId/10092>, January $29^{\text {th }}, 2015$. 
Aylward, Bruce and Edward B. Barbier (1992), "Valuing environmental functions in developing countries", Biodiversity and Conservation, 1 (1), Springer, Amsterdam, pp. 34-50.

Bailey, Jennifer L. (2012), "Whale watching. The Buenos Aires Group and the politics of the International Whaling Commission", Marine Policy, 36 (2), Elsevier, London, pp. 489-494.

Barbier, Edward B. (1991), "Environmental degradation in the third world", in David Pearce (ed.), Blueprint 2. Greening the world economy, Earthscan, London, pp. 75-108.

Breceda, Aurora, Aradit Castellanos, Laura Arriaga and Alfredo Ortega (1995), "Nature conservation in Baja California Sur, Mexico", Natural Areas Journal, 15 (3), Natural Areas Association, Bend, Oregon, pp. 267-273.

Brenner, Ludger and Hubert Job (2012), "Challenges to actor-oriented environmental governance: examples from three Mexican Biosphere Reserves", Tijdschrift voor Economische en Sociale Geografie, 103 (1), Royal Dutch Geographical Society, Utrecht, pp. 1-19.

Brenner, Ludger and Cristina de la Vega Leinert (2014), "La gobernanza participativa de Áreas Naturales Protegidas. El caso de la Reserva de la Biosfera El Vizcaíno", Región y Sociedad, núm. 59, El Colegio de Sonora, Hermosillo, pp. 183-213.

Chape, Stuart Mark Spalding and Martin D. Jenkins (2008), The world's protected areas, University of California Press, Berkeley.

Cisneros-Montemayor, Andrés M., Ussif Rashid Sumaila, Kristin Kaschner and David Pauly (2010), "The global potential for whale watching”, Marine Policy, 34 (6), Elsevier, London, pp. 1273-1278.

Conanp (Comisión Nacional de Áreas Naturales Protegidas) (2014a), "Resultados del conteo de de la Ballena Gris 1995/96 a 2013/14", unpublished document, Conanp, Mexico.

Conanp (Comisión Nacional de Áreas Naturales Protegidas) (2014b), "Resultados del conteo de de la Ballena Gris. 1996 a 2014", unpublished document, Conanp, Mexico. 
Dedina, Serge and Emily Young (1995), Conservation and development in the grey whale lagoons of Baja California Sur, Mexico, Final Report to the United States' Marine Mammal Commission, United States' Marine Mammal Commission, Tucson.

Dixon, John A. and Paul B. Sherman (1990), Economics of protected areas. $A$ new look at benefits and costs, Island Press, Washington.

Farber, Stephen, Robert Constanza and Matthew A. Wilson (2002), "Economic and ecological concepts for valuing ecosystem services", Ecological Economics, 41 (3), Elsevier, London, pp. 375-392.

Gallagher, Austin J. and Neil Hammerschlag (2011), "Global shark currency: the distribution, frequency, and economic value of shark ecotourism", Current Issues in Tourism, 14 (8), Taylor and Francis, London, pp. 797-812.

Hanley, Nick and Edward B. Barbier (2009), Pricing nature. Cost-benefit analysis and environmental policy, Edward Elgar Publishing, Cheltenham.

Heckel, Gisela, Stephen B. Reilly, James L. Sumich and Ileana Espejel (2001), "The influence of whalewatching on the behaviour of migrating grey whales (Eschrichtius robustus) in Todos Santos Bay and surrounding waters, Baja California, Mexico", Journal of Cetacean Research and Management, 3 (3), International Whaling Commission, Cambridge, pp. 227-237.

Herrera, Guillermo and Porter Hoagland (2006), "Commercial whaling, tourism, and boycotts: An economic perspective", Marine Policy, No. 30, Elsevier, London, pp. 261-269.

Higham, James E. S. and David Lusseau (2008), "Slaughtering the goose that lays the golden egg: Are whaling and whale watching mutually exclusive?", Current Issues in Tourism, 11 (1), Taylor and Francis, London, pp. 63-74.

Hoyt, Erich (2001), Whale watching 2001: Worldwide tourism numbers, expenditures, and expanding socioeconomic benefits, International Fund for Animal Welfare, Yarmouth Port.

Hoyt, Erich (2005a), "Sustainable ecotourism on Atlantic islands, with special reference to whale watching, marine protected areas and 
sanctuaries for cetaceans", Biology and Environment: Proceedings of the Royal Irish Academy, 105B (3), Royal Irish Academy, Dublin, pp. 141-154.

Hoyt, Erich (2005b), Marine protected areas for whales, dolphins, and porpoises: A world handbook for cetacean habitat conservation, Earthscan, London.

Hoyt, Erich and Miguel Iñíguez (2008), "The State of Whale watching in Latin America", Chippenham-United Kingdom, <http://www. wdcs.org/submissions_bin/WW_Latinamerica_English.pdf>, August 16 $6^{\text {th }}, 2012$.

INE (Instituto Nacional de Ecología) (2000), Programa de manejo/Reserva de la Biosfera El Vizcaíno, Instituto Nacional de Ecología, Mexico.

Inegi (Instituto Nacional de Estadística y Geografía) (2014), Censo de población y vivienda 2010, Instituto Nacional de Estadística y Geografía, Mexico.

Job, Hubert, Felix Kraus, Cornelius Merlin and Manuel Woltering (2013), Wirtschaftliche Effekte des Tourismus in Biosphärenreservaten Deutschlands, Landwirtschaftsverlag, Bonn-Bad Godesberg.

Job, Hubert and Marius Mayer (2012), "Forstwirtschaft versus Waldnaturschutz: Regionalwirtschaftliche Opportunitätskosten des Nationalparks Bayerischer Wald", Allgemeine Forst-und Jagd-Zeitung, 183 (7-8), J. D. Sauerländersverlag, Frankfurt, pp. 129-144.

Job, Hubert, Manuel Woltering and Bernhard Harrer (2009), Regionalökonomische Effekte des Tourismus in deutschen Nationalparken, Landwirtschaftsverlag, Bonn-Bad Godesberg.

Leiper, Neil (1990), "Tourist attraction systems", Annals of Tourism Research, 17, Elsevier, London, pp. 367-384.

Mayer, Marius (2014), "Can nature-based tourism benefits compensate for the costs of national parks? A study of the Bavarian Forest National Park. Germany", Journal of Sustainable Tourism, 22 (4), Taylor and Francis, London, pp. 561-583. 
Mayer, Marius and Hubert Job (2014), "The economics of protected areas-a European perspective", Zeitschrift für Wirtschaftsgeographie, 58 (2-3), Buchenverlag, Bad Soden, pp. 73-97.

Mayer, Marius (2013), Kosten und Nutzen des Nationalparks Bayerischer Wald. Eine ökonomische Bewertung unter Berücksichtigung von Tourismus und Forstwirtschaft, Oekom, Munich.

Mayer, Marius, M. Müller, Manual Woltering, Julius Arnegger and Hubert Job (2010), "The economic impact of tourism in six german national parks", Landscape and Urban Planning, 97 (2), Elsevier, London, pp. 73-82.

MEA (Millennium Ecosystem Assessment) (2005), Ecosystems and human well-being: Synthesis, Island Press, Washington.

Miller, Tom (1975), The world of the California grey whale, Baja Trail Publications, Santa Ana, California.

Moisey, Neil R. (2002), "The economics of tourism in National Parks and Protected Areas", in P. F. J. Eagles and S. F. MacCool (eds.), Tourism in national parks and protected areas. Planning and management, Cab International, New York, pp. 235-253.

Munasinghe, Mohan (1992), "Biodiversity protection policy: Environmental valuation and distribution issues", Ambio, 21 (3), Springer, Hamburg, pp. 227-236.

Newsome, David, Susan A. Moore and Ross K. Dowling (2002), Natural area tourism: ecology. Impacts and management, Channel View Publications, Clevedon.

Orams, Mark B. (2002), "Humpback whales in Tonga: An economic resource for tourism", Coastal Management, 30 (4), Taylor and Francis, London, pp. 361-380.

Orams, Mark B. (2013), "Economic activity derived from whale-based tourism in Vava'u, Tonga", Coastal Management, 41 (6), Taylor and Francis, London, pp. 481-500.

Ortega-Rubio, Alfred, Aradit Castellanos-Vera and Salvador Emilio LluchCota (1998), "Sustainable development in a Mexican Biosphere Reserve: Salt production in Vizcaíno. Baja California (Mexico)", 
Natural Areas Journal, 18 (1), Natural Areas Association, Bend Oregon, pp. 63-72.

Parsons, Edward C. M. and Megan M. Draheim (2009), "A reason not to support whaling - a tourism impact case study from the Dominican Republic", Current Issues in Tourism, 12 (4), Taylor and Francis, London, pp. 397-403.

Parsons, E. C. M., C. A. Warburton, A. Woods-Ballard, A. Hughes and P. Johnston (2003), "The value of conserving whales: the impacts of cetacean-related tourism on the economy of rural WestScotland", Aquatic Conservation: Marine and Freshwater Ecosystems, No. 13, John Wiley and Sons, London, pp. 397-415.

Pascual, Unai, Muradian Roldan (coords.) (2010), "The economics of valuing ecosystem services and biodiversity", in P. Kumar (ed.), The economics of ecosystems and biodiversity: Ecological and Economic Foundation, Earthscan, London, pp. 183-256.

Pearce, David W. and Dominic Moran (1994), The economic value of biodiversity, Earthscan, London.

Pearce, David W. and R. Kerry Turner (1990), Economics of natural resources and the environment, Harvester Wheatsheaf, London.

Primack, Richard B. (1995), Naturschutzbiologie, Spektrum Akademischer Verlag, Heidelberg.

Randall, A. and J. Stoll (1983), "Existence values in a total valuation framework", in: R. D. Row and L. G. Chestnut (eds.), Managing air quality and scenic resources at National Parks and Wilderness Areas, Westview Press, Boulder, pp. 265-274.

Ritter, Fabian (2004), Wale beobachten. Ein Leitfaden zum sanften Whale watching in Europa und Übersee, Conrad Stein Verlag, Welver.

Stadler, Claudia (2007), "Effekte des Naturtourismus in einem Großschutzgebiet. Das Beispiel Whale watching im Biosphärenreservat El Vizcaíno (Mexiko)", master's thesis, Universidad LudwigMaximilian de Munich, Institute of Econonic Geography, Munich. 
Weisbrod, Burton A. (1964), "Collective-consumption services of individual-consumption goods", The Quarterly Journal of Economics, 78 (3), Oxford University Press, Oxford, pp. 471-477.

Woltering, Manuel (2012), “Tourismus und Regionalentwicklung in deutschen Nationalparken: Regionalwirtschaftliche Wirkungsanalyse des Tourismus als Schwerpunkt eines sozioökonomischen Monitoringsystems”, Würzburger Geographische Arbeiten 108/, Institut für Geographie und Geologie der Julius-MaximiliansUniversität Würzburg \& Geographische Gesellschaft Würzburg, Würzburg, <http://opus.bibliothek.uni-wuerzburg.de/frontdoor/ index/index/docId/6015>, January 29 ${ }^{\text {th }}, 2015$.

Wunder, Sven (2007), "The efficiency of payments for environmental services in tropical conservation", Conservation Biology, No. 21, John Wiley and Sons, London, pp. 48-58.

Young, Emily (1999a), "Local people and conservation in Mexico's El Vizcaíno Biosphere Reserve", Geographical Review, 89 (3), John Wiley and Sons, London, pp. 364-390.

Young, Emily (1999b), "Balancing conservation with development in small-scale fisheries: is ecotourism an empty promise?", Human Ecology, 27 (4), Springer, Hamburg, pp. 581-620.

Young, Michael Denis (1992), Sustainable investment and resource use. Equity, environmental integrity, and economic efficiency, Parthenon Publication Group and Unesco, Paris.

Recibido: 2 de marzo de 2015. Reenviado: 28 de septiembre de 2015. Aceptado: 29 de octubre de 2015.

Ludger Brenner. PhD in geography from the University of Trier, Germany, is a fulltime professor at the Department of Sociology at the Metropolitan Autonomous University, Mexico City. He is a member of the National System of Researchers, level II. His research interests include tourism, geography and environmental governance. His most recent publications are, coauthored: "Red de participación institucional en las áreas naturales protegidas de la península de Baja California”, Región y Sociedad, 62, El Colegio de Sonora, Hermosillo, pp. 27-62 (2015); 
coauthored, Geografía de la gobernanza: dinámicas multiescalares de los procesos económico-ambientales, Siglo XXI-Universidad Autónoma Metropolitana unidad Iztapalapa, Mexico City (2015) and, coauthored, "Kann organische Kaffeeproduktion nachhaltiges Land-sharing fördern? Erfahrungen aus dem Unesco-Biosphärenreservat Los Tuxtlas (Mexiko)", in Karl-Heinz Erdmann, Hans-Rudolf Bork y Hubert Job, Bonn (eds.), Naturschtuz in geographischer Perspektive, Bundesamt für Naturschutz, Germany, pp. 109-122 (2015).

Marius Mayer. PhD in geography from the Julius Maximilian University at Würzburg, Germany, is an assistant professor at the Institute of Geography at the Ernst-Moritz-Arndt University at Greifswald, Germany. His research interests include economic geography, regional development, management of protected areas and ecotourism. He has published numerous papers in peer-reviewed international journals, such as: "Can nature-based tourism benefits compensate for the costs of national parks? A study of the Bavarian Forest National Park, Germany", Journal of Sustainable Tourism, 22 (4), Routledge, pp. $561-583$ (2014); coauthored, The economics of protected areas - a European perspective, Zeitschrift für Wirtschaftsgeographie, 58 (2/3), De Gruyter, pp. 73-97 (2014); coauthored "From conflict to partnership? Interactions between protected areas, local communities and operators of tourism enterprises in two German national park regions", Journal of Tourism and Leisure Studies, 17 (2), Tourism and Leisure Studies, pp. 147-181 (2011).

Claudia Stadler. Holds a master's degree in economic geography from the Ludwig-Maximilian University of Munich, Germany. Her thesis (2007) deals with economic impacts of nature-based tourism in Mexico. Currently she works at the WIB Consulting Group in Berlin/Germany. 